\title{
Quem será? Sagarana e o chamado do mistério, das trevas e do amor
}

\author{
Who will be? Sagarana and the call of mystery, \\ darkness and love
}

\author{
Ermelinda Maria Araújo Ferreira*
}

Resumo: Sagarana marca a estreia de um médico interiorano em crise, deprimido após um pífio segundo lugar obtido em sua primeira e esperançosa empreitada literária. Prestes a abandonar a profissão e o sonho para dedicar-se ao serviço burocrático no Itamaraty, Guimarães Rosa deflagra seu destino viator: levado a estranhas paragens, familiariza-se com o sublime e o grotesco, na descoberta da generosa paixão de Ara e do fescenino ódio de Hitler. De volta ao Brasil, a reescritura deste livro aponta para uma guinada na percepção do autor, que escolhe, antes, abraçar os mistérios do grande sertão a apartar-se deles em nome de uma ciência racional e dogmática, alheia ao amor e ao espírito: desalmada.

Palavras-chave: Guimarães Rosa, Sagarana, medicina, ciência, trevas, cegueira

\begin{abstract}
Sagarana marks the debut of a small-town doctor in crisis, depressed by a paltry second place result in his first literary competition. About to leave the profession and the dream in order to dedicate himself to the bureaucratic service in the Foreign Ministry, Guimarães Rosa triggers his viator destination: taken to strange places, he becomes familiar with the sublime and the grotesque, through the discovery of the generous love of Ara and of the fescenine hatred of Hitler. Back in Brazil, the rewriting of this book points to a shift in the perception of the author; who chooses rather to embrace the mysteries of the great "sertão" than to depart from them in the name of a rational and dogmatic science, without love and spirit: soulless.
\end{abstract}

Keywords: Guimarães Rosa, Sagarana, medicine, science, shadows, blindness

\footnotetext{
Professora Doutora do Programa de Pós-Graduação em Letras e do Departamento de Letras da Universidade Federal de Pernambuco (UFPE).
} 
Para esta menina sarar, pensava Tistu, é preciso que ela deseje ver o dia seguinte. Uma flor, com sua maneira de abrir-se, de avisar surpresas, poderia talvez ajudá-la. Uma flor é uma verdadeira adivinhação, que recomeça cada manhã. ... - E então, Tistu, perguntou o doutor Milmales, que foi que você aprendeu? Que sabe de medicina? - Aprendi que a medicina não pode nada contra um coração muito triste. Aprendi que para a gente sarar é preciso ter vontade de viver. Maurice Druon

Temos pálpebras nos olhos, mas não temos pálpebras nos ouvidos, pois os ouvidos são os portais da aprendizagem, e a natureza pretendeu mantê-los sempre bem abertos. Não contente com negar-nos esta proteção, ela também nos impediu-entre todos os demais ouvintes - de mover as nossas orelhas. Só o homem tem orelhas fixas, imóveis, sempre em alerta, como guardiões da entrada dos sons do mundo. A natureza não queria que nos distraíssemos, e perdêssemos um único segundo na tarefa de aguçarmos a nossa audição. Por isso, os ouvidos se mantêm a postos indefinidamente, mesmo quando a alma se retira para seus aposentos. Na verdade, é nestas horas que eles, como sentinelas do espírito, mantêm-se mais acordados. Caso contrário, a quem caberia avisar-nos do perigo? Quando a mente se retira para descansar, a quem caberia acordá-la? Tal é a diferença entre ver e ouvir. Enquanto os olhos buscam as coisas que deliberadamente querem ver, as coisas que precisam ser ouvidas nos chegam espontaneamente aos ouvidos.

Baltasar Gracián 
agarana, primeiro livro de contos do médico escritor Guimarães Rosa, nasceu com nome de doença infecciosa: "Sezão", que significa febre intermitente ou periódica, transmitida pelo mosquito Anopheles, também conhecida como Malária ou Paludismo. Segundo o autor, o livro surgiu em 1937, "quase todo escrito na cama, a lápis, em cadernos de 100 folhas, de 20 de maio a 4 de dezembro, em sete meses de exaltação e de deslumbramento" (ROSA, 2001, p. 25). Em novembro deste ano, o autor contratou uma datilógrafa para passar o texto a limpo, entregando-o depois, em 31 de dezembro, na Livraria José Olympio, para concorrer ao prêmio Humberto de Campos. Deu ao volume um título provisório e genérico: Contos, assinando-o com o pseudônimo "Viator". O livro ganhou o segundo lugar no concurso, perdendo para Maria Perigosa, de Luís Jardim, com o famoso voto de Minerva conferido por Graciliano Ramos. Esse voto muito arrependimento custaria ao mestre, conforme ele viria a confessar algumas vezes. No texto "Um livro inédito", de sua coletânea de crônicas Linhas tortas, por exemplo, provavelmente escrito em 1938 - e ainda no desconhecimento da identidade de "Viator"-, Ramos afirma que a obra merece urgente publicação, revelando as principais razões que o teriam induzido ao infeliz julgamento: ${ }^{1}$

Votei contra esse livro de Viator. Votei porque dois dos seus contos me pareceram bastante ordinários: a história dum médico morto na roça, reduzido à condição de trabalhador de eito ... e algumas páginas campanudas, entre elas uma que cheira a propaganda de soro antiofídico, me deram arrepio e me afastaram do vasto calhamaço de quinhentas páginas. ... Viator desapareceu sem deixar vestígio. Desgostei-me: eu desejava sinceramente vê-lo crescer, talvez convencer-se de que me havia enganado preterindo-o. (RAMOS, 1986, p. 24, itálicos nossos)

A principal ressalva de Graciliano Ramos, como se percebe, terá sido ao conto "Bicho mau", talvez por ser o que mais claramente denunciava a decepção do autor com a realidade fadada ao exercício da profissão da medicina nas medonhas

\footnotetext{
1 É preciso lembrar que o livro foi burilado, e a versão que hoje se frequenta difere muito do original, como mostra Maria Neuma B. Cavalcante, em sua tese de doutoramento "Bicho mau". A gênese de um conto (USP, 1991). Na longa versão enviada ao concurso, disponível no arquivo do escritor no IEB, constam vinte páginas extras, detalhando os conflitos entre o médico e o fazendeiro, nas quais se acentua a empáfia retórica do jovem bacharel.
} 
entranhas do Brasil. Esta constatação, e o resultado do concurso, certamente contribuíram para a grande mudança que operou em sua vida: a desistência da profissão e o afastamento, ainda que provisório, da literatura. Aprovado na seleção para o Ministério das Relações Exteriores, Guimarães Rosa é nomeado cônsul adjunto em Hamburgo, deixando o Brasil para dar início a uma experiência radicalmente diferente. Sagarana "repousaria", portanto, durante os sete anos desta fase que Ihe trouxe tantas mudanças; entre elas, o encontro com Aracy Moebius de Carvalho, sua grande e definitiva paixão. Poliglota, ela também prestava serviços ao Itamaraty na Alemanha, durante a Segunda Guerra Mundial. O período foi turbulento, e a atuação do casal resultou determinante na fuga de muitos judeus perseguidos pelo Nazismo. A iniciativa trouxe consequências quando do rompimento das relações do Brasil com a Alemanha em 1942. Rosa e Aracy ficaram presos durante quatro meses, aguardando a troca com diplomatas alemães. Anos depois, em abril de 1985, receberam a mais alta distinção que os judeus prestam a estrangeiros: o nome do casal foi dado a um bosque que fica ao longo das encostas que dão acesso a Jerusalém.

A reescritura de Sagarana coincide, assim, com o final da guerra. Em 1945, portanto, o livro, segundo o autor, foi retrabalhado em cinco meses de reflexão e de lucidez. O projeto inicial, que consistia numa reunião de doze contos, foi reduzido para nove, sendo três estórias retiradas da versão que veio a público com o título definitivo. É indubitável a importância da numerologia na obra de Guimarães Rosa. Segundo os estudiosos do tema, "doze" e "nove" são algarismos equivalentes no que diz respeito à economia simbólica; assinalando, ambos, um fim e um recomeço, o fechamento de um ciclo e o início de um novo movimento na espiral da vida. A retirada do conto "Bicho mau", que só viria a ser publicado, postumamente, no volume Estas estórias, parece sugestiva. Afinal, como disse Graciliano Ramos, era impossível não perceber um desagradável pedantismo na primeira versão deste verdadeiro elogio à ciência, e sua supremacia sobre o misticismo popular. Os personagens regionais, com suas crenças e medos próprios de outro registro cultural, são ridicularizados de modo muito similar ao que acontece, por exemplo, ao Jeca Tatu de Monteiro Lobato, sobre o qual recai toda a culpa dos desmandos e do atraso civilizatório do país.

Portador de "amarelão" ou Ancilostomíase, verminose causada pelo parasita Ancylostoma duodenale, Jeca Tatu conseguiu promover a ciência com muito mais ênfase do que o "sezão" ou a Malária teria sido capaz, mesmo constando 
no título de uma obra de relevo como a da estreia do grande Guimarães Rosa. Isto porque, apesar do tom afetado do texto, as experiências do mineiro, funcionário público, talvez estivessem, desde o início, mais ancoradas à realidade do interior do Brasil do que a do rico fazendeiro e empresário de sucesso Monteiro Lobato. Afinal, como médico em Itaguara, pequena cidade do município de Itaúna em Minas Gerais, Rosa foi obrigado a fazer intermináveis viagens no lombo de um cavalo, e a permanecer por cerca de dois anos no seio de comunidades muito simples - convivendo com raizeiros e receitadores.

A favor de Lobato é preciso dizer que a medicina de base natural - a arte de linha hipocrática que contrapôs a observação metódica à imaginação desordenada, a física à metafísica e o prodígio do comum aos milagres de essência sobrenatural - sempre lutou contra a ideia da origem divina ou diabólica dos males, e sempre agiu contra a sedimentação da doença como estigma. A ciência, inegavelmente, trouxe imenso progresso, não só para a cura dos males do corpo como do espírito, colaborando para afastar os medos e seus tentáculos ainda mais danosos que as próprias doenças. Susan Sontag analisa os males psicológicos dos mecanismos de estigmatização das epidemias sem cura desde a antiguidade - Lepra, Sífilis, Tuberculose - até a modernidade, quando um diagnóstico de Câncer, Aids ou Ebola é tratado como uma sentença de morte de cunho obsceno, ao qual se deve associar um sentimento de vergonha e de culpa.

Tal situação ainda persiste nos rincões geográficos e culturais onde o entendimento dos sofrimentos físicos e mentais, e de seus possíveis tratamentos, ainda resta solidamente inscrito numa concepção animista do mundo, da qual se originam os mitos. E um dos mitos que a ideia de um Brasil atrasado veio sedimentando desde a modernidade foi o do fracassado, portador da patologia da ignorância sobre os avanços do mundo dito civilizado, e dos danos que o seu alijamento na partilha das conquistas econômicas e tecnológicas do Ocidente viria a causar, comprometendo a saúde da nação.

Este mito ganhou força simbólica na obra de Monteiro Lobato, por meio do famoso conto de sua coletânea Urupês (1918), que contém histórias do trabaIhador rural paulista, mas que acaba criando uma caricatura generalizada do matuto brasileiro do interior. Inicialmente concebido para criticar a passividade do homem do campo, o Jeca ganha novos contornos durante as campanhas sanitaristas do início do século XX no Brasil, quando passa a ser utilizado pelo autor como arauto da esperança de redenção do brasileiro pela ciência médi- 
ca. O comportamento do Jeca ganha finalmente uma explicação - a doença -, e uma esperança de cura pela educação, adoção de hábitos de higiene e mudança de hábitos alimentares. A imagem redimida do caboclo - agora próspero, saudável e rico - passa, então, a circular em folhetins, e o "Jeca Tatuzinho" acaba se tornando o garoto propaganda do Almanaque Fontoura - financiado pelo medicamento que prometia a cura do "amarelão". Responsável pelo estado anêmico que justificava a apatia do caboclo, atribuía-se ao "amarelão", entre outras coisas, a incompreensível falta de entusiasmo do brasileiro para a adoção dos princípios desenvolvimentistas importados do "Primeiro Mundo", os quais mudariam a cara da nossa nação atrasada.

Interlocutor de Guimarães Rosa, Monteiro Lobato talvez tenha influenciado o jovem médico escritor nos seus primeiros voos nas duas profissões, conforme sugere Lucciani M. Furtado em seu livro $O$ visitante. Não surpreende, pois, que "Bicho mau", submetido aos princípios higienizadores e progressistas de Lobato, falasse da presença da cascavel nos campos destinados à agricultura como de um "mal necessário" - a espécie ainda sobrevivendo -, mas cuja peçonhice, mortal para as vítimas desavisadas, estaria já plenamente neutralizada, controlada pelo soro antiofídico: solução clara, asséptica e funcional como a razão humana. A ciência abria, com o entusiasmo dos modernistas - e a golpes de foice desferidos pelo médico letrado, seu discurso intelectual e sua tecnologia farmacológica -, não apenas o cerrado bioma do espaço geográfico exterior, mas suas ramificações interiores ainda mais espinhosas e entranhadas na mente e na alma dos habitantes das regiões inóspitas do Brasil profundo.

"Bicho mau" partilha, assim, com "Jeca Tatu", o pendor pedagogizante das entradas e bandeiras nacionalistas da saúde pública em seus primórdios, empenhada em descrever o homem do campo como um capiau essencialmente ignorante e doente; afundado em crendices e pajelanças deletérias. Ao contrário de estratégias de sobrevivência postas à prova desde uma ancestralidade impossível de calcular, a sabedoria desse povo, baseada em longo e íntimo convívio com a mata e seus habitantes, era taxada simplesmente de "curandeirismo" - patologia decorrente do analfabetismo que excluía o brasileiro comum da cultura livresca dos nossos colonizadores e de sua inegável sapiência. A falta de "informação" científica, no Brasil, era considerada ainda mais mortal, segundo os iniciados, do que a própria peçonha da serpente maligna conspurcadora do Éden. 
O Guimarães Rosa de "Bicho mau", consultor de Monteiro Lobato, certamente considerou a possibilidade de se tornar um arauto do progresso por meio de sua contribuição literária. O fato de constatar, como médico, a eficiência do soro antiofídico, por exemplo: capaz de salvar, com simplicidade, uma vida, de outro modo condenada a grande suplício e à morte - conforme faz questão de relatar no seu conto -, talvez o fizesse corroborar, quiçá com veemência, a postura do velho mestre.

Foi só depois, quando levado a conhecer de perto, na sua nova missão como embaixador do Brasil na Alemanha de 1938 a 1945, a outra face do projeto desenvolvimentista europeu, que a literatura do jovem cientista parece sofrer um abalo irrecuperável. A inenarrável barbárie da Segunda Guerra Mundial, portanto, deixou marcas profundas no autor.

Do projeto inicial de Sezão conservou o conto "Sarapalha", sobre o qual comenta em carta a João Condé: "Desta, da história desta história, pouco me lembro. No livro, será ela, talvez, a de que menos gosto" (ROSA, 1991, p. 26). Curiosa observação, por ser "Sarapalha" exatamente a história que fala da doença que daria título, originalmente, à obra. A mudança do título para Sagarana, que comporta a valorização do contador de histórias do povo, pela inserção de um termo tupi, com o qual vem a identificação maior do autor - "semelhante a", também chama a atenção. "Semelhante a" uma "saga" - termo germânico, com o qual não há, deliberadamente, um vínculo direto. O livro se reconhece como um vago reflexo do gênero de origem, e é com uma diç̧ão nativa que escolhe fazer esta sugestão. O ponto de vista muda significativamente, se considerarmos que o título anterior usava a terminologia popular "Sezão", a qual, no confronto com a perspectiva de "Bicho mau", revelava a intenção crítica da obra e sua condenação da ignorância popular. Essa ignorância que identifica as doenças com seu próprio e tosco vocabulário - e que tudo desconhece da sabedoria do autor, a fazer valer, vaidosa e ingenuamente, a sua formação como médico.

Sete meses para nascer, sete anos para amadurecer, cinco meses para renascer: essa é a fórmula de Sagarana. Comentaremos, portanto, a mudança de enfoque da obra numa breve análise de três significativas histórias: "Sarapalha", "Corpo fechado" e "São Marcos", nesta ordem, pois acreditamos que ela traduz os passos do narrador rumo a uma iluminação imprevisível, ao insight que funcionaria como reviravolta na sua perspectiva de observação e compreensão da realidade, além de uma guinada nos rumos que tomaria a sua poética. A fim de 
facilitar a reflexão, escolhemos comentar como Rosa retrata, nesses contos, a figura do médico - ainda marcadamente presente como um seu alterego.

Em "Bicho mau", o médico, como Deus, está simplesmente ausente do arraial interiorano. Evocada em desespero pela esposa de um agonizante seu Quinquim, vítima da Boicininga, a ciência envia, contudo, a salvação por meio do farmacêutico, o anjo plantonista (igualmente invisível e inacessível), que manda o estojo com as seringas e as ampolas. Só mais tarde, o médico é novamente requisitado para dar parecer sobre o desequilíbrio emocional da mulher do Quinquim, após a morte do marido. Novamente, é retratado como figura distante no meio: "um moço de fora". Não conseguindo estabelecer um diálogo verdadeiro com Nhô de Barros, velho fazendeiro que se recusa - por questão de foro íntimo - a aplicar as injeções no filho, a postura do personagem levanta problemas, como a condenação das políticas públicas de saúde no interior, com o distanciamento do médico de província da população, e sua inoperância no sentido de estabelecer contato e conquistar a confiança das comunidades. $O$ resultado da ausência de sua intervenção pedagógica na mudança de hábitos e crenças arraigados resulta no fortalecimento das crendices e no fracasso dos tratamentos, com o prejuízo do alto investimento do governo em medicamentos e equipamentos modernos, e, consequentemente, a continuidade das mortes que poderiam ser evitadas.

O curandeiro é desmerecido e mesmo denegrido no discurso do estrangeiro; conquanto defendido pelo morador, cujo conhecimento da terra, dos bichos e dos homens do lugar não pode ser negado, pela precisão de sua descrição da espécie de cobra responsável pelo ataque, e pela (cautelosa) consideração que revela para com o preto velho Jerônimo Benzedor:

Não teriam, acaso, dado ao doente algum remédio de curandeiro? Garrafada, calomelano com caldo de limão? Sabia-se que era mantido, ali, na fazenda, como agregado, um desses, charlatão... - “- É um velho, um coitado. Dá-se casa p'ra ele morar, e três alqueires p'ra plantar, à terça..." Ou teria sido outra qualidade de cobra? Teriam reconhecido bem a cascavel? "- Sim senhor, seu doutor. Isto sim, era cascavel mesmo, mesma, ela tinha mudado de novo, estava bem repintada, tinha chocalho, um cornimboque de quatorze campainhazinhas, só..." (ROSA, 1991, p. 260) 
Ao contrário deste jovem inquisidor - que mais parte teria com o Santo Ofício do que com a Santa Casa da Misericórdia -, o médico retratado no conto "Sarapalha" apresenta outra postura. Cremos que homenageia, discretamente, tantas e tão curiosas figuras empenhadas como ele, que se embrenharam Brasil afora, às vezes fugindo à realidade da guerra, para fazer valer o seu sonho salvacionista em terras distantes, muitas vezes inóspitas. Mais do que com o Jeca Tatu, portanto, o conto parece dialogar com o romance $A$ majestade do Xingu, do também médico escritor Moacyr Scliar, narrado em primeira pessoa no estilo de Grande sertão: veredas - e que discorre sobre a história de um desses sanitaristas, o imigrante judeu russo Noel Nutels, e suas atividades junto aos índios brasileiros da Amazônia.

O anônimo médico de Rosa é, antes de tudo, um idealista. Mas também é um pesquisador sério, envolvido com o conhecimento teórico e com a sua aplicabilidade prática. Seu empenho educativo beira a insanidade, ao contrair a malária, deliberadamente, para provar ao povo que ela não se pega com as frutas, nem com o ar, nem com a água; mas com a picada do mosquito. Sua presença efetiva na cidadezinha, e sua ação missionária, contudo, também resultam ineficientes. O povo aceita a nova explicação, baseada na comprovação factual promovida pelo agente da ciência, e ingere o quinino, com todos os efeitos colaterais. Entretanto, o remédio não cura o mal nem expulsa os agentes etiológicos, incapazes de serem controlados por ações de fumigação e extermínio, pela vastidão da mata onde imperam. Assim, as pessoas continuam a morrer e acabam por abandonar a povoação.

Por pertinentes que sejam, essas questões, no entanto, não figuram primordiais à história, como em "Bicho mau". Postas em segundo plano, restam quase imperceptíveis pelo relevo que é dado ao conflito pessoal entre dois moradores remanescentes, Primo Argemiro e Primo Ribeiro - pacientes crônicos de malária, condenados à morte, mas unidos pelo amor da mesma mulher foragida, e pelo segredo de inconfessada traição entre eles. A doença incomoda, mas é suportada. O que resulta insuportável é a ausência da amada, a traição revelada, a dor do engano, a culpa de um e a impossibilidade da vingança do outro. A noção de saúde, longe de se coadunar com a definição de um corpo sem doenças, funcionante como uma máquina bem azeitada para o trabalho - conforme a percepção da ciência -, amplia-se para incluir elementos impalpáveis, como a sobrevivência dos sonhos, a vigência dos afetos, aquilo que no humano ultrapas- 
sa o plano da matéria. Neste conto, Guimarães Rosa insere uma ideia imprevista em "Bicho mau": os homens não morrem apenas quando seus corpos deixam de funcionar, mas quando suas vidas perdem o sentido. Assim, os estremeços da malária surgem como simulacros - cópias platônicas, distantes - dos estremeços do amor tão desejados e contidos, jamais vividos pelo Primo Argemiro:

Ai! que o frio cai entre os ombros, vai pelas costas, e escorre das costas para o corpo todo, como fios de água fina. Zoa nos ouvidos confuso sussurro, e para diante dos olhos vêm coisinhas, querendo dançar. Ir, para onde? ... Não importa, para a frente é que a gente vai!... Mas, depois. Agora é sentar nas folhas secas, e aguentar. O começo do acesso é bom, é gostoso: é a única coisa boa que a vida ainda tem. (ROSA, 1991, p. 173, itálicos nossos)

De personagem secundário, o médico adquire, afinal, um maior relevo como narrador do conto "Corpo fechado", em constante diálogo com o protagonista, Manuel Fulô: corruptela de "flor" que se estende ao nome da mula de estimação do capiau, Beija-Fulô; mas que também evoca conhecido poema de Jorge de Lima, "Essa Nega-Fulô"; o qual, em ritmo de modinha popular, narra os dissabores, mas também celebra, maliciosamente, as vitórias das escravas nos solares. Essa alusão coincide com o projeto das epígrafes de Sagarana, buscadas a letras de provérbios e de cantigas de roda, de batuque e de espanta-males.

O desnível do discurso do intelectual com o do morador permanece e se mantém pelo tom cômico da narrativa e pela forma desigual como se estabelece a amizade entre ambos, adotando o médico uma postura paternal, algo divertida e condescendente com o homenzinho contador de histórias. Este, por sua vez, aproveita a notoriedade do médico para se valorizar perante a vizinhança. $A$ narrativa resume-se, como sempre, a uma meditação sobre as estratégias do poder e suas articulações nos mais diversos contextos. A figura do curandeiro retorna, e a rivalidade da magia com a ciência adquire ares de disputa, pelo menos no imaginário do povo que, agora, passa a ecoar o discurso "civilizacionista". Internalizado e verbalizado por Manuel Fulô, esse discurso só aflora, contudo, por conta de desavenças pessoais, estando o Fulô contrariado com o Toniquinho das Pedras: 
Tenho ódio dele, tenho mesmo!... É o pior pedreiro do arraial, não sabe nem plantar uma parede. Sabe é fazer feitiço, vender garrafada de raiz do mato, e rezar reza brava. Tem partes com o porco-sujo... Não presta! Gente assim não devia de ter!... Ele vive desencaminhando o povo de ir se consultar com o senhor. Dizendo que o doutor-médico não cura nada, que ele sara os outros muito mais em conta, baratinho... Ele quer plantar mato na sua roça e frigir ovo no seu fogão! O senhor não vê? Ele não faz receita no papel, só porque não conhece os símplices, e acho que não sabe escrever, e isso que nem o boticário não aviava nenhuns-nada... Qualquer dia ele arruma uma coisa-feita, p'ra modo de fazer o senhor ir-s'embora daqui... O senhor devia era de fazer medo nele, falando em mandar vir um tenente com os soldados, se ele não parar com esses embondos de feitiço... O senhor porque é bom demais, e não vê que ele está mas é roubando o de-comer de seus filhos... (ROSA, 1991, p. 315)

A fala de Manuel Fulô, descontada a raiva e o desejo de fomentar a intriga, denuncia o drama social da inserção do médico nos ambientes rurais. Quem, de fato, tinha o "de-comer dos filhos" ameaçado pela chegada do profissional acadêmico, formado e ilustrado, da cidade - chegada esta, abalizada e protegida pelas forças militares, se preciso -, era o "feiticeiro", até então a única referência da população para o alívio de seus males. Magia e ciência não dialogam e não trabalham juntas. Não se observa, no médico, interesse em se aproximar do Toniquinho. A medicina moderna é imposta de fora, e deve ser acatada apesar de seu preço, evidentemente muito mais oneroso para a população do que o cobrado pelo curandeiro local. Os mecanismos de sujeição do povo ao abuso de poder, porém, vêm de longe; e o conto - que focaliza justamente a figura do "valentão" - mostra a violência da aculturação, enquanto instrumento de imposição de novas crenças e hábitos a um povo. O conto de Guimarães Rosa fala de como a medicina científica é introduzida no interior do Brasil mediante os mesmos princípios de coerção usados no cotidiano político, social e de convívio familiar naqueles ermos. O povo aceita o médico como aceita o delegado, o coronel, o cigano e o cangaceiro. Aceita o médico, como aceita a Crotalus durissus, o Anopheles, o Ancylostoma. Aceita o médico como suporta o envenenamento, a malária e o amarelão.

O curioso, nesta história, é o desfecho. Assistimos à progressiva queda da postura autossuficiente do médico, cuja intervenção se torna verdadeiramente inú- 
til no desenredo, quando Manuel Fulô, acovardado, prefere se esconder e deixar sua noiva ser deflorada pelo mandão da cidade, numa abusada demonstração de força. Foge o delegado, o coronel lava as mãos e o padre promete rezar. Sem salvação possível vinda de alguma autoridade, a situação se resolve pela inesperada intervenção da providência. E tudo se dá como um simples negócio, um mero acordo de cavalheiros, como narra o médico:

Mas, de fato, cartas dadas, a história começa mesmo é aqui. Porque: era uma vez um pedreiro Antonico das Pedras, que tinha alma de pajé; e tinha também uma sela mexicana, encostada por falta de animal, e cobiçada ainda a Beija-Fulô, a qual era o grande amor do meu amigo Manuel Fulô. Pois o Antonio curandeirofeiticeiro, apesar de meu concorrente, lá me entrou de repente em casa, exigindo o Manuel Fulô a um canto - para assunto secretíssimo. ... Aí, de chofre, abriu a porta do quarto-da-sala e o Antonico das Pedras surgiu, muito cínico e sacerdotal, requisitando agulha-e-linha, um prato fundo, cachaça e uma lata com brasas. $\mathrm{E}$ Manuel Fulô reapareceu também, muito mais amarelo do que antes, dizendo ao povo funebremente: - Podem entregar a minha Beija-Fulô p'ra o seu Toniquinho, que ela agora é dele. ... Só perguntaram: - O que que o senhor foi fazer com meu irmão, seu Toniquinho? - Fechei o corpo dele. Não careçam de ter medo, que para arma de fogo eu garanto!... (ROSA, 1991, p. 322)

O que se seguiu pareceu um milagre aos olhos da cidade expectante. Manuel Fulô, de desancado e bêbado, covarde e derrotado, vê nascer no íntimo a força e a saúde de um herói, partindo para o brutamontes Targino e escapando da saraivada de balas que ele the desfere. Com uma voz "que de tão enérgica eu desconhecia", disparou então um grito de guerra, avançou no homem e crivou-o de facadas, com uma "faquinha quicé quase canivete", "tudo com rara elegância e suma precisão": "Targino desviveu num átimo" (ROSA, 1991, p. 324).

Neste conto, o narrador não esclarece a essência do milagre, fomentando no leitor a hesitação tão cara a Tzvetan Todorov, em sua famosa definição do fantástico na literatura. O curandeiro apenas teria, como qualquer médico, "vendido" o seu conhecimento, tanto por um motivo nobre, como por interesses pessoais. O "mal" - numa dimensão mais ampla, e encarnado em ser vivente nomeado "Targino" - é definitivamente arrancado do arraial, com uma eficiência compro- 
vada e superior à da ciência do médico de "Sarapalha", por exemplo, incapaz de erradicar o surto de malária de seu rincão, com a fraca energia de seu quinino. ${ }^{2}$

Concluímos esta reflexão com algumas considerações sobre o misterioso conto "São Marcos", um dos mais elaborados de Guimarães Rosa, que reincide no tema da medicina versus a magia com grande pertinácia, e desta feita já sem a mais ínfima hesitação todoroviana. Apesar de relatar em filigrana um caso de feitiçaria comprovado, já não resta nenhuma dúvida para o médico que vivencia a experiência: as veredas da saúde e da doença são mais profundas do que parecem, e definitivamente escapam ao poder de visão dos luminares da ciência moderna. Tanto é que o médico narrador, numa direta e irônica alusão a "Bicho mau", anuncia, logo abaixo da sentença taxativa com que abre o conto: "- Naquele tempo eu morava no Calango-frito e não acreditava em feiticeiros"; o "contrassenso que mais avultava", inegável referência ao acidente que matou seu Quimquim: o fato de trazer consigo, dobrado na carteira, "fórmula gráfica que garantia invulnerabilidade à picada de ofídios: mesmo de uma cascavel em jejum, pisada na ladeira da antecauda..." (ROSA, 1991, p. 262).

Cegos! - é como parece chamar a todos os encarnados no médico João, narrador e protagonista, "xará" de pássaros como o joão-de-barro, o joão-grande e o joão-pinto, que a meio da história muda o nome para José - Zé, e depois Izé - comparado a outro ínfimo qualquer: "Zé-Prequeté, que se equilibrava em cima dos saltos arqueados de um pangaré neurastênico, quando o cavalicoque cobreou com o lombo e, com um jeito de rins e depois um desjeito, deu com o meu homônimo no chão." (ROSA, 1991, p. 265). O médico "caiu do cavalo", literalmente, nesta história, e com tamanho vexame que não teve alternativa senão ceder a outro o direito à exclusividade do uso do seu nome próprio, em paga pelo reconhecimento do erro. História em que não cabiam dois Joões, pois. E o outro era "preto; pixaim alto, branco amarelado; banguela; horrendo", mas também era João: João Mangolô. Esta história é, portanto, uma homenagem

\footnotetext{
2 Semelhante "procedimento" terapêutico e higienizador será reforçado no conto "A hora e a vez de Augusto Matraga", cujo desfecho reproduz, em linhas gerais, o de "Corpo fechado" - aludindo o autor à mesma "possessão" mansa, necessária à promoção da "saúde coletiva" que acomete o "agente sanitário" Matraga, ao pegar no instrumento necessário à "cirurgia" de extirpação, do seio do corpo comunitário, da "tumoração" que representa o homem perverso. A barbárie humana é tida, portanto, como verdadeira entidade nosológica, na longa e profunda meditação de Guimarães Rosa sobre a doença como o mal, e sobre o mal como doença, que é a sua obra.
} 
respeitosa a este feiticeiro, e talvez mesmo uma confissão ritualística da iniciação pessoal de seu autor - como adepto, e não mais apenas como neófito - nas "artes das trevas".

Pois o que as trevas têm de interessante para a medicina é que elas impõem, à cartesiana superioridade da visão, a soberania da audição. Ouvir é o requisito máximo para a realização de uma boa anamnese, por exemplo, instrumento fundamental ao médico na formulação de um diagnóstico. Em última instância - e para utilizar uma terminologia de Jacques Derrida -, a anamnese consiste na tentativa de realização de uma "otobiografia": a escuta interessada da história narrada pelo outro, mediante um exercício de empatia com o seu sofrimento. Só assim é possível elaborar uma narrativa da doença, tal como ela acomete o sujeito em sua totalidade, tal como ela é percebida e relatada por ele. E só assim é possível entender a missão de um escritor vocacionado, e da literatura como o chamado do desconhecido. A literatura, como o doente, também carece deste ouvinte empático, paciente e afetuoso, capaz de atravessar com ele um sertão.

Esse tema é de suma importância para Guimarães Rosa, sendo retomado diversas vezes em sua obra. Ele está na origem mesma de tudo, vem dos recônditos da infância e adquire azo de parábola na novela autobiográfica "Campo geral", uma entre as sete reunidas no monumental Corpo de baile, lançado dez anos depois de Sagarana. Miguilim é uma criança míope, irmão amicíssimo de Dito, uma criança condenada. Visão e audição se imiscuem, e o caminho para a luz da razão - com o consequente afastamento das eloquentes trevas da intuição - é traçado por uma história que culmina com a aparição reveladora de um médico. Como sempre, "Um senhor de fora, de óculos, corado, alto e claro" (ROSA, 1991, p. 148). O doutor José Lourenço, do Curvêlo, que fará o diagnóstico da deficiência visual do menino, a prescrição dos óculos e a proposta de uma nova vida na cidade grande, com "estudo e aprendizado de um ofício" (ROSA, 1991, p. 150). Miguilim hesita, o Mutum inteiro num adeus, a saudade. Mas o chamado da luz - o apelo do caminho da direita - era muito forte:

Nem não podia acreditar! Tudo era uma claridade, tudo novo e lindo e diferente, as coisas, as árvores, as caras das pessoas. Via os grãozinhos de areia, a pele da terra, as pedrinhas menores, as formiguinhas passeando no chão de uma distância. $E$ tonteava. Aqui, ali, meu Deus, tanta coisa, tudo... (ROSA, 1991, p. 149) 
Muitos anos depois - depois mesmo da confissão do engano, do mergulho voluntário nas trevas e da opção deliberada pelo caminho sinistro -, um velho míope relata seu amor e sua dívida para com o Dito morto. Tornar-se cego parece representar, na reescritura de Sagarana, a volta ao início, o fechamento do círculo, e uma nova e definitiva abertura para as "primeiras estórias": as estórias que ele nomearia e reconheceria como inaugurais, escritas sob o signo do Dito, em atenção ao chamado das sombras. "Quem será?" - pergunta que se repete em "São Marcos", mas que se perpetua em uma obra voltada ao desvelamento do engano. Uma obra que começa guiada pela mente científica, responsável pelos progressos tecnológicos mais importantes da história, mas que padece de uma inclinação para a intolerância e o preconceito, representados na atitude perversa e escarnecedora do doutor João para com o curandeiro João. Mesmo alertado pelos amigos, gente do povo, a cozinheira Sá Nhá Rita Preta e o mameluco Aurísio Manquitola, o doutor "arrasta mala", "enjeriza", ri deliberadamente do outro e de suas crenças: "E eu abusava, todos os domingos, porque, para ir domingar no mato das Três Águas, o melhor atalho renteava o terreirinho de frente da cafua do Mangolô, de quem eu zombava já por prática. Com isso eu me crescia, mais mandando..." (ROSA, 1991, p. 263).

Adentrando-se, progressivamente, com um olhar descritivo de naturalista esmiuçador, num mato simbólico mapeado como uma câmara de iniciação - não faltando referências a Pã, Egito, Vênus etc. - o doutor João mergulha cada vez mais fundo em si mesmo, nas suas supostas andanças, entabulando estranho diálogo com interlocutor anônimo, popular ("meu melhor amigo aqui no Calango-frito"), nas inscrições feitas a canivete ou a lápis na pele dos bambus falantes, rumorejantes aos voos dos ventos: "Meus bambus. Meus? Nossos... Porque eles são a base de uma subestória, ainda incompleta." (ROSA, 1991, p. 273).

A subestória se desenrola na pele envernizada e lisíssima dessas plantas asiáticas, e reconta a reescritura de Sagarana. Como num autêntico desafio de repentistas, o João das palavras difíceis e raras enumera suas listas ocas e sonoras de reis leoninos, terminologia científica, latim dos padres e comandos mágicos, sendo sumariamente desancado, em suas razões, pelo adversário - a voz do povo -, que desfecha: "Língua de turco rabatacho dos infernos" (ROSA, 1991, p. 275). Não convencido, conquanto já abalado, volta a atacar, agora cedendo ao apelo do estilo do outro, simplório, buscado aos contos e modinhas populares, respondendo ao verso em que afirma que "Na viola do urubu o sapo chegou no 
céu". Ainda recusando a sugestão de ascensão facultada ao feio pássaro preto e agourento, o doutor João responde com a história do lindo e colorido surucuá, que cai, foragido, na terra. E lança o ultimato: "Ou a perfeição, ou a pândega!". E a resposta vem no domingo seguinte: "Chegando na encruzilhada/eu tive de resolver:/para a esquerda, fui, contigo./Coração soube escolher!". "O tema se esgotara, com derrota minha e o triunfo de 'Quem-Será'” (ROSA, 1991, p. 277); afirmação que implica, de fato, em não ter havido resposta do outro. Foi, portanto, o próprio doutor João que capitulou ao chamado do mistério, das sombras, do enigma do coração: como eco do Dito, como anunciação de Diadorim. "Quem-Será"- razão maior oculta à vista, à lógica e à ciência dos homens, mas amiga dos homens, dos sonhos dos homens, de suas dores e alegrias, da poesia. “-Guenta o relance, Izé...". E assim, comprovando na prática a eficácia da reza brava a "São Marcos e São Manços", e o poder ofensivo do grosseiro manipanso com olhos amarrados por tirinha de pano preto - "p'ra Sinhô passar uns tempos sem poder enxergar e não precisar de ver negro feio..." (ROSA, 1991, p. 291) -, o médico Guimarães Rosa parece fazer as pazes com todos os curandeiros e feiticeiros do mundo. $\mathrm{O}$ reconhecimento do erro, e mesmo o acatamento do engano, porém, não parecem suficientes para desbancar a soberba do grande escritor. Ao contrário. A descoberta é "gloriosa", ele se sente "magnânimo" com seus novos poderes - tanto que fica à vontade para ameaçar o desafeto e desembolsar um modesto valor pelo "acordo de paz". E a conclusão não poderia ser mais inesperada, mais conflitante, mais desafiante a toda a nossa humilde e provavelmente equivocada argumentação. Porque as últimas palavras deste Joãozezim voltam ao início, ao entusiasmo de Miguilim, à correção da miopia como um bem (outra miopia?), reafirmando novamente o poder da luz, da claridade, da lucidez: "Mas recobrara a vista. E como era bom ver!". 


\section{Referências}

CHEVALIER e GHEERBRANT. Dicionário de símbolos. Rio de Janeiro: José Olympio, 1990. DERRIDA, Jacques. Otobiografías. La enseñanza de Nietzsche y la política del nombre proprio. Buenos Aires: Amorrortu, 2009.

DRUON, Maurice. O menino do dedo verde. Rio de Janeiro: José Olympio, 2006.

FURTADO, Lucciani M. O visitante. São Paulo: Baraúna, 2014.

GRACIÁN, Baltasar. Espelho de bolso para heróis. Lisboa: Edições Temas da Actualidade, 1996.

LOBATO, Monteiro. Urupês. São Paulo: Globo, 2009.

RAMOS, Graciliano. Linhas tortas. Rio de Janeiro: Record, 1986.

ROSA, Guimarães. Sagarana. Rio de Janeiro: Nova Fronteira, 2001.

. Carta de João Guimarães Rosa a João Condé, revelando segredos de Sagarana. In

ROSA, Guimarães. Sagarana. Rio de Janeiro: Nova Fronteira, 2001.

. Estas estórias. Rio de Janeiro: Nova Fronteira, 2001.

. Manuelzão e Miguilim. Corpo de Baile. Rio de Janeiro: Nova Fronteira, 2001.

SCLIAR, Moacyr. A majestade do Xingu. São Paulo: Companhia das Letras, 1997.

SONTAG, Susan. Doença como metáfora. São Paulo: Companhia das Letras, 2007.

TODOROV, Tzvetan. Introdução à literatura fantástica. São Paulo: Perspectiva, 2008.

VITAL, Michelle Jácome Valois. "O microcosmo que geme e o macrocosmo que dança: o médico Guimarães Rosa 'diante de Deus e do infinito'". In Intersemiose - revista digital. Ano 1, v. 1, N. 1, Jan/Jul 2012, p. 187. (http://www.neliufpe.com.br. Acesso em: 10/10/2015).

Submetido em: 27-08-2015 Aprovado para publicação: 25-10-2015 